\title{
OCCURRENCE AND INTENSITY OF PARASITES IN GOLDFISH (Carassius auratus L.) FROM GUILAN PROVINCE FISH PONDS, NORTH IRAN
}

\section{Javad Daghigh Roohi ${ }^{1}$, Kobra Ghasemzadeh ${ }^{2}$, Masoomeh Amini ${ }^{1}$}

'Iranian Fisheries Science Research Institute, Inland Water Aquaculture Research Centre, Agricultural Research Education and Extension Organization (AREEO), Bandar-e-Anzali, Iran

${ }^{2}$ Fisheries Department, Faculty of Natural Resources, University of Guilan, SowmehSara, Iran

*Corresponding Author, Email: javad_daghigh@yahoo.com

\section{ARTICLE INFO}

Received: 29 June 2015

Received in revised form: 21 December 2015

Accepted: 18 December 2015

Available online: 24 December 2015

\section{ABSTRACT}

In this survey 109 specimens of goldfish (Carassius auratus) were collected from Guilan fish ponds during 2012-13. After recording biometric characteristics, common parasitology methods were used. In the present study 11 parasite species were recovered from goldfish. Parasitofauna consisted of two protozoans: Ichthyophthirius multifiliis and Trichodina sp.; one digenean trematodes: Diplostomum spathaceum; six monogenean trematodes: Dactylogyrus vastator, Dactylogyrus formosus, Dactylogyrus baueri, Dactylogyrus anchoratus and Gyrodactylus sp.; one crustacean: copepodid stage of Lernaea cyprinacea and one nematodes larvae. All the monogeneans found during the current study are considered new locality records for goldfish in Guilan province, Iran. Mean intensity of infection and abundances of parasite species (with prevalences $>10 \%$ ) among seasons were tested by the Kruskal-Wallis test (KW, multiple comparisons) and Conover-Inman test. Results have shown that monogeneans had the highest prevalence values $(49.54 \%)$ in goldfish in Guilan fish ponds.

Roohi, J. D., Ghasemzadeh, K., Amini, M. (2016): Occurrence and intensity of parasites in goldfish (Carassius auratus L.) from Guilan province fish ponds, north Iran. Croatian Journal of Fisheries 74, 20-24. DOI: 10.1515/cjf-2016-0004

\section{INTRODUCTION}

Goldfish (Carassius auratus L.), a freshwater fish in the Cyprinidae family, is one of the earliest cultured ornamental fish in the world (Tu et al., 2015). This species originally inhabits rivers, lakes, ponds and ditches with stagnant or slow flowing water. Goldfish occur in eutrophic waters, well vegetated ponds and canals. Their feeding is mainly on plankton, benthic invertebrates, plant material and detritus (Kottelat and Freyhof, 2007). This species has been brought to Iran from Eastern Asia for ornamental purposes about 80 years ago. Iranian people buy a few goldfish in a crystal bowl for celebrating the New Year known as Nowruz. For this reason in Iran goldfish is regularly cultured as a commodity fish in some of the warm-water fish ponds. Parasites of goldfish in different parts of the world have been reported by several authors (Ogawa and Egusa, 1979; Jalali and Molnar, 1990;
Levsen, 1995; Di Cave et al., 2000; Koyun and Altunel, 2007; Koyuncu, 2009 and Borisov, 2013). The monogenean fauna of goldfish in Japan was studied by Ogawa and Egusa (1979) who found six species of Dactylogyrus (D. dulkeiti, $D$. formosus, $D$. baueri, $D$. intermedius, $D$. anchoratus and D.vastator). Koyun and Altunel (2007) studied parasites of goldfish in Enne Dam Lake of Turkey and they discovered that goldfish were infected with two species of monogenean (Dactylogyrus anchoratus and Gyrodactylus katherineri) and one nematode (Contracaecum sp.). Borisov (2013) investigated the representatives of the Dactylogyridae family in imported goldfishes to Bulgaria from Singapore and he found five typical Dactylogyrus for goldfish (D. vastator, D. formosus, $D$. intermedius, $D$. anchoratus and $D$. baueri) as well. It can be concluded from these researches that goldfish can be considered one of the most common hosts of dactylogirids. 
Parasites can have a considerable impact on the growth and behavior of fish (Scholz, 1999) and cause mortality in cases of high parasitic burden. The aim of the present study was to investigate the helminth fauna of one of the most popular ornamental fish $C$. auratus in Guilan fish ponds, as a main center of goldfish cultivation in Iran, as well as their epizootiological aspects through calculating their prevalence, intensity, abundance and dominance.

\section{MATERIALS AND METHODS}

A total of 109 goldfish Carassius auratus were collected from Guilan province fish farms, north Iran. The fishes were caught from September 2012 to August, transported to the Parasitology Laboratory of National Inland Water Aquaculture Research Institute in Anzali city alive in water obtained from the collection site. A dissolved oxygen saturation of approximately $85-90 \%$ was maintained during transport. Upon arrival, fish were killed by a sharp blow to the head, weighed and measured and then examined externally for gross signs of parasitism. If no gross signs were observed, skin biopsies were prepared from the entire length of the lateral body wall. Goldfish (109 in number) averaged $18.44 \mathrm{~g}( \pm 34.51 \mathrm{~g}$, range $=1-308 \mathrm{~g})$ in weight and averaged $9.25 \mathrm{~cm}( \pm 3.62 \mathrm{~cm}$, range $=3.5-28 \mathrm{~cm}$ ) in total length. A gill biopsy was collected from the second arch of specimens. A fin biopsy was collected from the caudal fin of specimens. Wet mounts of all biopsied tissues were prepared for further analysis.

After recording biometric characteristics, standard necropsy and parasitology methods were used (Stoskopf, 1993). All organs of the fish were examined except for blood. Live trematodes were relaxed in distilled water at $4^{\circ} \mathrm{C}$ for $1 \mathrm{~h}$ and fixed in $10 \%$ hot buffered formalin. The worms were identified using parasite identification keys (Yamaguti, 1961; Bykhovskaya-Pavlovskaya et al., 1962; Moravec, 1994) and then deposited at the Laboratory of Fish Diseases of National Inland Water Aquaculture Research Institute (Iran). Classical epidemiological variables (prevalence, intensity and abundance) were calculated according to Bush et al. (1997). The dominance of a parasite species was calculated as $\mathrm{N} / \mathrm{N}$ sum (where $\mathrm{N}=$ abundance of a parasite species and $\mathrm{N}$ sum $=$ sum of the abundance of all parasite species found) and expressed as a percentage (modified after Leong \& Holmes, 1981). The dominance values were used for classification of parasites as eudominant ( $>10 \%)$, dominant ( $5.1 \%-10 \%)$, subdominant $(2.1 \%-5 \%)$, recedent $(1.1 \%-2 \%)$ and subrecedent $(<1.0 \%)$ of given species (Niedbala and Kasparzak, 1993). Mean intensity of infection and abundances of parasite species (with prevalences $>10 \%$ ) among seasons were tested by the Kruskal-Wallis test (KW, multiple comparisons) and Conover-Inman test. Results were considered significant at the $95 \%$ level $(p<0.05)$. Computations were performed using the SPSS. 15 programme.

\section{RESULTS}

In the present study two protozoan and nine metazoan parasites, including members of the parasite taxa: Nematoda, Digenea, Monogenea and Copepoda, were determined (Table 1). The prevalence (P), mean intensity of infection (MI), range, mean abundance (MA) and dominance percentage of the parasites are presented in Table 1. The eudominant parasite of goldfish (Table 1 ) were monogeneans and Trichodina sp. (Dominance $=\mathrm{D}=47.33 \%$ and $42.78 \%$, respectively). The subdominant parasites were $D$. spathaceum $(\mathrm{D}=4.03)$, $I$. multifiliis $(D=2.86 \%)$ and $L$. cyprinacea $(D=2.86 \%)$. The only subrecedent parasite was nematoda larvae $(D=0.13)$.

As it is shown in Table 1 , monogeneans (including $D$. vastator, $D$. intermedius, $D$. formosus, $D$. baueri, $D$. Anchoratus and Gyrodactylus sp.) indicate the highest prevalence values $(49.54 \%)$ in goldfish (Fig. 1).

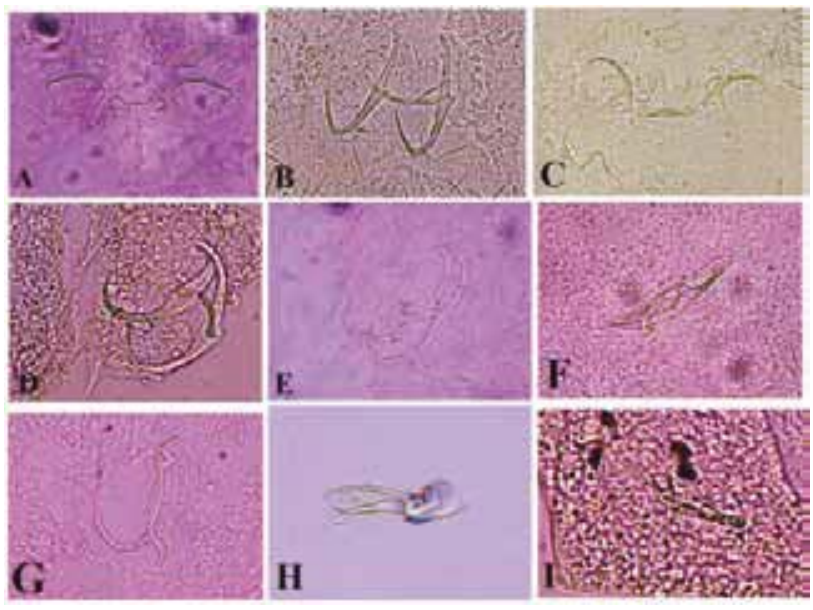

Fig 1. Monogeneans recovered from goldfish (Carassius auratus) in Guilan fish ponds (A to E consist of the attachment apparatus: A) D. vastator B) D. baueri C) $D$. intermedius D) D. formosus E) D. anchoratus; F to I the copulatory organ: F) $D$. vastator $\mathrm{G}) D$. baueri $\mathrm{H}) D$. intermedius I) D. formosus)

According to Table 2, the abundance of Lernaea cyprinacea in summer was significantly higher than in other seasons (Conover-Inman test, $\mathrm{p}<0.05$ ). It was also true for abundance of Trichodina sp. in autumn which was significantly higher than in summer (Conover-Inman test, $p<0.05$ ).

In Table 3 the prevalence of parasites in different length groups had varying values and the differences between them were significant for $D$. spathaceum, Trichodina sp. and monogenean parasites $(p<0.05)$. There was a positive correlation between fish length, fish weight and infection to Trichodina sp. and D. spathaceum. Conover-Inman test also demonstrated most differences are between small fish and the large ones. 
Table 1. The prevalence, mean intensity, range, abundance and dominance of some parasites in goldfish (C. auratus)

\begin{tabular}{cccccc}
\hline \hline Parasite & Prevalence(\%) & Mean \pm SD & Range & Abundance \pm SD & Dominance(\%) \\
\hline $\begin{array}{c}\text { D.spathaceum } \\
\mathrm{N}=31\end{array}$ & 11.00 & $2.58 \pm 1.31$ & $1-5$ & $0.28 \pm 0.91$ & 4.03 \\
$\begin{array}{c}\text { Trichodina sp. } \\
\mathrm{N}=329\end{array}$ & 32.11 & $9.4 \pm 12.22$ & $1-74$ & $3.01 \pm 8.15$ & 42.78 \\
$\begin{array}{c}\text { I. multifilis } \\
\mathrm{N}=22\end{array}$ & 4.58 & $4.4 \pm 6.06$ & $1-15$ & $0.2 \pm 1.48$ & 2.86 \\
$\begin{array}{c}\text { Monogenean* } \\
\mathrm{N}=364\end{array}$ & 49.54 & $6.53 \pm 4.85$ & $1-25$ & $3.21 \pm 4.73$ & 47.33 \\
$\begin{array}{c}\text { L. cyprinacea } \\
\mathrm{N}=22 \\
\text { Nematoda } \\
\mathrm{N}=1\end{array}$ & 11.92 & $1.69 \pm 0.94$ & $1-3$ & $0.20 \pm 0.63$ & 2.86 \\
\hline \hline
\end{tabular}

* Consisting of $D$. vastator, $D$. intermedius, $D$, formosus, D. baueri, $D$. anchoratus, and Gyrodactylus sp.

Table 2. The prevalence, mean intensity, range and abundance of some parasites of $C$. auratus in different seasons

\begin{tabular}{|c|c|c|c|c|c|c|}
\hline Seasons & $\begin{array}{c}\text { D. spathaceum } \\
\text { Prevalence(\%) } \\
\text { Mean } \pm S D \\
\text { Abundance } \pm S D \\
\text { Range } \\
\end{array}$ & $\begin{array}{c}\text { Trichodinasp. } \\
\text { Prevalence(\%) } \\
\text { Mean } \pm \text { SD } \\
\text { Abundance } \pm S D \\
\text { Range } \\
\end{array}$ & $\begin{array}{c}\text { I. multifiliis } \\
\text { Prevalence(\%) } \\
\text { Mean } \pm \text { SD } \\
\text { Abundance } \pm \text { SD } \\
\text { Range }\end{array}$ & $\begin{array}{c}\text { Monogenean* } \\
\text { Prevalence(\%) } \\
\text { Mean } \pm \text { SD } \\
\text { Abundance } \pm \text { SD } \\
\text { Range }\end{array}$ & $\begin{array}{c}\text { Lernaea } \\
\text { Prevalence(\%) } \\
\text { Mean } \pm S D \\
\text { Abundance } \pm S D \\
\text { Range }\end{array}$ & $\begin{array}{c}\text { Nematoda } \\
\text { Prevalence(\%) } \\
\text { Mean } \pm S D \\
\text { Abundance } \pm S D \\
\text { Range }\end{array}$ \\
\hline $\begin{array}{l}\text { Summer } \\
(\mathrm{N}=48)\end{array}$ & $\begin{array}{c}6.25 \\
2.0 \pm 1.73 \\
0.12 \pm 0.60^{\mathrm{a}} \\
1-4\end{array}$ & $\begin{array}{c}9.17 \\
4.40 \pm 3.30 \\
0.91 \pm 2.31^{\mathrm{a}} \\
1-10\end{array}$ & $\begin{array}{c}4.16 \\
2.50 \pm 2.12 \\
0.10 \pm 0.59^{\mathrm{a}} \\
1-4\end{array}$ & $\begin{array}{c}45.83 \\
5.45 \pm 3.60 \\
2.50 \pm 3.65^{\mathrm{a}} \\
1-13\end{array}$ & $\begin{array}{c}27.08 \\
1.69 \pm 0.94 \\
0.45 \pm 0.89^{b} \\
1-3\end{array}$ & $0^{a}$ \\
\hline $\begin{array}{l}\text { Autumn } \\
(\mathrm{N}=53)\end{array}$ & $\begin{array}{c}16.98 \\
2.77 \pm 1.20 \\
0.47 \pm 1.15^{\mathrm{a}} \\
1-5\end{array}$ & $\begin{array}{c}45.28 \\
11.62 \pm 14.15 \\
5.26 \pm 11.07^{b} \\
2-74\end{array}$ & $\begin{array}{c}3.77 \\
1.0 \pm 0.0 \\
0.03 \pm 0.19^{a} \\
1\end{array}$ & $\begin{array}{c}49.05 \\
7.56 \pm 6.06 \\
3.56 \pm 5.61^{\mathrm{a}} \\
1-25\end{array}$ & $0^{a}$ & $0^{\mathrm{a}}$ \\
\hline $\begin{array}{c}\text { Winter } \\
(N=8)\end{array}$ & $0^{a}$ & $\begin{array}{c}12.5 \\
6.00 \pm- \\
0.75 \pm 2.12^{\mathrm{ab}} \\
6\end{array}$ & $\begin{array}{c}12.5 \\
15.0 \pm- \\
1.87 \pm 5.30^{\mathrm{a}} \\
15\end{array}$ & $\begin{array}{c}75.00 \\
6.83 \pm 2.31 \\
5.12 \pm 3.72^{\mathrm{a}} \\
3-10\end{array}$ & $0^{a}$ & $\begin{array}{c}12.5 \\
1.00 \pm- \\
0.12 \pm 0.35^{\mathrm{a}} \\
1\end{array}$ \\
\hline
\end{tabular}

* Consisting of D. vastator, D. intermedius, D. formosus, D. baueri, D. anchoratus and Gyrodactylus sp.

** Data shown with different letters in each column are statistically significant at the $p<0.05$ level.

Table 3. The prevalence, mean intensity, standard deviation and maximum intensity of parasites of $C$. auratus in different sizes

\begin{tabular}{|c|c|c|c|c|c|c|}
\hline $\begin{array}{c}\text { Parasite } \\
\text { Size class } \\
\text { TL }(\mathrm{cm})\end{array}$ & $\begin{array}{c}\text { D. spathaceum } \\
\text { Prevalence (\%) } \\
\text { Mean } \pm \text { SD } \\
\text { Max intensity }\end{array}$ & $\begin{array}{c}\text { Trichodina sp. } \\
\text { Prevalence (\%) } \\
\text { Mean } \pm \text { SD } \\
\text { Max intensity }\end{array}$ & $\begin{array}{c}\text { I. multifiliis } \\
\text { Prevalence (\%) } \\
\text { Mean } \pm \text { SD } \\
\text { Max intensity }\end{array}$ & $\begin{array}{c}\text { Monogenean* } \\
\text { Prevalence (\%) } \\
\text { Mean } \pm \text { SD } \\
\text { Max intensity }\end{array}$ & $\begin{array}{c}\text { Lernaea } \\
\text { Prevalence (\%) } \\
\text { Mean } \pm \text { SD } \\
\text { Max intensity }\end{array}$ & $\begin{array}{c}\text { Nematoda } \\
\text { Prevalence (\%) } \\
\text { Mean } \pm \text { SD } \\
\text { Max intensity }\end{array}$ \\
\hline $\begin{array}{c}\quad 6< \\
\text { Small } \\
(N=17)\end{array}$ & $0^{\mathrm{a}}$ & $\begin{array}{c}5.88 \\
0.58 \pm 2.42^{\mathrm{a}} \\
10\end{array}$ & $0^{\mathrm{a}}$ & $\begin{array}{c}35.29 \\
2.29 \pm 3.53^{\mathrm{ab}} \\
11\end{array}$ & $\begin{array}{c}23.52 \\
0.52 \pm 1.06^{\mathrm{a}} \\
3\end{array}$ & $0^{a}$ \\
\hline $\begin{array}{c}6.1-12 \\
\text { Medium } \\
(N=78)\end{array}$ & $\begin{array}{c}10.25 \\
0.28 \pm 0.95^{\mathrm{ab}} \\
5\end{array}$ & $\begin{array}{c}33.33 \\
3.29 \pm 9.23^{\mathrm{ab}} \\
74\end{array}$ & $\begin{array}{c}3.84 \\
0.07 \pm 0.47^{a} \\
4\end{array}$ & $\begin{array}{c}55.12 \\
3.67 \pm 5.11^{\mathrm{b}} \\
25\end{array}$ & $\begin{array}{c}11.53 \\
0.16 \pm 0.54^{a} \\
3\end{array}$ & $\begin{array}{c}1.28 \\
0.01 \pm 0.11^{\mathrm{a}} \\
1\end{array}$ \\
\hline $\begin{array}{c}12.1> \\
\text { Large } \\
(\mathrm{N}=14)\end{array}$ & $\begin{array}{c}28.57 \\
0.64 \pm 1.15^{b} \\
3\end{array}$ & $\begin{array}{c}57.14 \\
4.42 \pm 5.44^{b} \\
18\end{array}$ & $\begin{array}{c}14.28 \\
1.14 \pm 3.99^{a} \\
15\end{array}$ & $\begin{array}{c}28.57 \\
0.50 \pm 0.94^{a} \\
3\end{array}$ & $0^{\mathrm{a}}$ & $0^{\mathrm{a}}$ \\
\hline
\end{tabular}

* Consisting of D. vastator, D. intermedius, D. formosus, D. baueri, D. anchoratus, and Gyrodactylus sp.

** Data shown with different letters in each column are statistically significant at the $p<0.05$ level 


\section{DISCUSSION}

Some of the parasites isolated from goldfish in Guilan fish ponds are capable of making significant mortalities among captive and wild stocks, especially parasites which do not need an intermediate host, such as protozoan and monogeneans. Isolated parasites in this study may be transferred from cultivated fish to aquarium fish. In the present study, monogeneans were responsible for the highest prevalence $(47.33 \%)$ in the gills and on the skin of sampled fish. Gills necropsies yielded the greatest diversity of parasites with eight taxa represented in this organ. $C$. auratus is a potential bearer of dactylogyrids and might be playing a role in their spreading not only in ornamental fish but also in fish from the natural ichthyofauna (Borisov, 2013). Dactylogyrus vastator, which is isolated from the sampled fish, is a highly pathogenic species and is usually observed on the gills of Carassius carassius, Carassius auratus gibelio and Cyprinus carpio (Gussev, 1985). D. vastator is rather widespread through freshwater lakes and fish farms where common carp inhabits or is cultivated (Shamsi et al., 2009). It is the most prevalent species of the monogeneans among fingerlings in the northern part of Iran (Guilan and Mazandaran provinces) and causes high injuries and mortalities (Jalali and Molnar, 1990). So the infection of Guilan goldfish with $D$. vastator is justifiable. On the other hand, $D$. anchoratus needs special attention due to its low host specificity and high tolerance to a wide range of temperature and salinity (Shamsi et al., 2009). This parasite attaches to the base of primary filaments where osmoregulating chloride cells are located. Therefore, infection with the parasite could be dangerous and harmful especially for the fry-size fish in hatcheries (Shamsi et al., 2009). D. intermedius is an important veterinary ectoparasite in Asia, Central Europe, Middle East and North America (Wang et al., 2011). D. intermedius may cause gill inflammation, excessive mucus secretions, accelerated respiration and mixed infections with another parasites and secondary bacterial infections. This parasite always leads to the loss of appetite, productivity and high mortalities (Wang et al., 2011). In recent years, the infestation of $D$. intermedius in freshwater fish has increased and caused serious economic damage (Wang et al., 2011). In Europe, D. intermedius has been found in goldfishes imported from Singapore (Di Cave et al., 2000) and in goldfishes from aquariums in Norway (Levsen, 1995). Typical for the species are anchors and a copulatory organ (Fig. 1, C and H). Comparing the results of the present study with the other researchers who referred that in past time just Dactylogyrus dulikeity was reported for Carassius auratus in Guilan fish ponds (Shamsi et al., 2009), but in the present study five other species $(D$. vastator, $D$. intermedius, $D$. formosus, $D$. baueri, $D$. anchoratus) are recovered. Goldfish parasite investigations in other parts of the country have shown that $D$. baueri was recovered previously in Semnan, Isfahan, Kashan, shahre-Kord and also from
Carassius gibelio in Guilan, D. vastator in goldfishes of Tehran, Semnan and Cyprinus carpio of Guilan, D. anchoratus in Isfahan, Kashan and shahre-Kord (Jalali and Molnar, 1990; Meshgi et al., 2006; Shamsi et al., 2009; Fadaei-Fard et al., 2010; Mehdizadeh-mud and Yarian, 2012, Daghigh Roohi et al., 2014). So all the monogeneans found during the current study are considered new locality records for goldfish in Iran. As mentioned above, some of monogeneans were imported by goldfish from Singapore to Bulgaria. So identification of fish parasites and quarantine before import to each country can make a limitation to parasite distribution between different localities.

\section{ACKNOWLEDGMENT}

The authors would like to thank Inland water aquaculture research centre for its equipment support.

\section{Sažetak}

\section{POJAVA I INTENZITET PARAZITA KOD ZLATNE RIBICE (Carassius Auratus L.) U RIBNJACIMA POKRAJINE GUILAN, SJEVERNI IRAN}

U ovom je istraživanju prikupljeno 109 primjeraka zlatne ribice (Carassius auratus) iz ribnjaka pokrajine Guilan tijekom 2012.-13. godine. Nakon određivanja biometrijskih karakteristika, koristile su se uobičajene metode parazitologije. Utvrđeno je 11 vrsta parazita kod zlatnih ribica. Parazitofauna se sastojala od dvije protozoe: Ichthyophthirius multifiliis i Trichodina sp.; od jedne digenean trematode: Diplostomum spathaceum; šest jednorodnih metilja (Monogenea) trematoda: Dactylogyrus vastator, Dactylogyrus formosus, Dactylogyrus baueri, Dactylogyrus anchoratus i Gyrodactylus sp.; jednog raka: copepodne faze Lernaea cyprinacea i jedne ličinke nematode. Svi jednorodni metilji pronađeni tijekom ovog istraživanja prvi put su zabilježeni kod zlatnih ribica u pokrajini Guilan, Iran. Srednji intenzitet infekcije i brojnost vrsta parazita (u prevalenciji > 10\%) među godišnjim dobima testiran je Kruskal-Wallis testom (KW, višestruke usporedbe) i Conover-Inman testom. Rezultati su pokazali da su jednorodni metilji imali najvišu prevalenciju (49.54\%) kod zlatnih ribica u ribnjacima pokrajine Guilan.

\section{REFERENCES}

Borisov, E. V. (2013): Representatives of Dactylogyridae family of the Monogenea class in goldgish (Carassius auratus auratus) imported in Bulgaria from Singapore. Bulgarian Journal of Agricultural Science, 19, 2, 237-242.

Bush, A. O., Lafferty, K. D., Lotz, J. M., Shostak, A. W. (1997): Parasitology meets ecology on its own terms. Journal of Parasitology, 83, 575-583.

Bykhovskaya-Pavlovskaya, I. E., Gusev, A. V., Dubinina, M. 
N., Izyumova, N. A., Smirnova, T. S., Sokolovskaya, A. L., Schtein, G. A., Shulman, S. S., Epshtein, V. M. (1962): Key to parasites of freshwater fishes of the USSR. Academy of Science of the USSR, Zoological Institute. 919 pp.

Daghigh Roohi, J., Sattari, M., Nezamabadi, H., Ghorbanpour, N. (2014): Occurrence and intensity of parasites in Prussian carp, Carassius gibelio from Anzali wetland, Southwest Caspian Sea. Iranian Journal of fisheries sciences, 13, 2, 276-288.

Di Cave, D., Berrilli, F., De Liberato, C., Orecchia, P., Kennedy, C. R. (2000): Risk of introduction of fish parasites through ornamental fish trade, Parasitologia, Roma 42, (Suppl.) 168 pp.

Fadaei-Fard, F., Raissy, M., Hoseini, S. R., Javedaneh-Nia, M. (2010): An investigation of ectoparasites of goldfish (Carassius auratusus L., 1758). Journal of Modern Veterinary Research, 2, 2, 17-24.

Gussev, V. A. (1985): Identifier of parasites of freshwater fishes of USSR fauna [in Russian]. II. L. Science, 425 pp.

Jalali, B., Molnar, K. (1990): Occurrence of monogeneans on freshwater fishes in Iran: Dactylogyrus pp. on cultured fish. Acta Veterinaria Hungarica, 38, 4, 239-242.

Kottelat, M., Freyhof, J. (2007): Handbook of European freshwater fishes. Publications Kottelat, Cornol and Freyhof, Berlin. 646 pp.

Koyun, M., Altunel, F. N. (2007): Metazoan parasites of Bleak (Alburnus alburnus) Crucian Carp (Carassius carassius) and Golden Carp (Carassius auratus) in Enne Dam lake, Turkey. Intenational Journal of Zoological Research, 3, 2, 98-100.

Koyuncu, C. E. (2009): Parasites of ornamental fish in Turkey. Bulletin of European Association of Fish Pathology, 29, 1, 25-27.

Leong, T. S., Holmes, J. (1981): Communities of metazoan parasites in open water fishes of Cold lake, Alberta. Journal of Fish Biology, 18, 693-713.

Levsen, A. (1995): Risk of introduction of fish parasites through ornamental fish trade: a northern perspective. Program and Abstracts of the 4th International Symposium of Fish Parasitology, Munich, Germany, October 3-7, pp. 55.
Mehdizadeh-mud, S., Yarian, N. (2012): Survey of prevalent Dactylogyrus spp. in goldfish of Semnan city [In Persian]. The $2^{\text {nd }}$ National Congress of Veterinary laboratory Sciences. 2012 December 12-13, Semnan University, Iran. P 146.

Meshgi, B., Eslami, A., Yazdani, H. (2006): Study on the Parasitic Infections of Aquarium Fishes around Tehran [In Persian]. Journal of Faculty of Veterinary Medicine, 61, 1, 1-5.

Moravec, F. (1994): Parasitic Nematodes of Freshwater Fishes of Europe, Kluwer Academic publishers. 473 pp.

Niedbala, W., Kasparzak, K. (1993): Biocenotic indexes used in the ordering and analysis of data in quantitative studies. In "Methods in soil zoology" (Gorney, M. \& Grum, M.). Elsevier, Amesterdam, pp. 379-396.

Ogawa, K., Egusa, S. (1979): Six species of Dactylogyrus (Monogenea: Dactylogyridae) collected from goldfish and carp cultured in Japan. Fish Pathology, 14, 1, 21-31.

Scholz, T. (1999): Parasites in cultured and feral fish. Veterinary Parasitology, 84, 317-335.

Shamsi, S., Jalali, B., AghazadehMeshgi, M. (2009): Infection with Dactylogyrus spp. among introduced cyprinid fishes and their geographical distribution in Iran. Iranian Journal of Veterinary Research, 10, 1, 70-74.

Stoskopt, M. K. (1993): Fish Medicine. W.B. Saunders, Philadelphia. 882 pp.

Tu, X., Ling, F., Huang, A., Wang, G. (2015): The first report of Dactylogyrus formosus Kulwiec, 1927 (Monogenea: Dactylogyridae) from goldfish (Carassius auratus) in central China. Parasitology Research. DOI 10.1007/s00436015-4474-3.

Wang, K. Y., Yao, L., Du, Y. H., Xie, J. B., Huang, J. L., Yin. (2011): Anthelmintic activity of the crude extracts, fractions, and osthole from Radix angelicae pubescentis against Dactylogyrus intermedius in goldfi sh (Carassius auratus) in vivo. Parasitology Research., Jan; 108, 1, 195200.

Yamaguti, S. (1961): The nematodes of vertebrate, Part I, II. Interscience publisher, New York, Systemahelmintum III. London. 679 pp. 